This item was submitted to Loughborough's Research Repository by the author.

Items in Figshare are protected by copyright, with all rights reserved, unless otherwise indicated.

\title{
Transformational leadership and organizational culture: the situational strength perspective
}

PLEASE CITE THE PUBLISHED VERSION

PUBLISHER

(C) IMechE / Professional Engineering Publishing

VERSION

VoR (Version of Record)

LICENCE

CC BY-NC-ND 4.0

\section{REPOSITORY RECORD}

Masood, Syed A., Samir Dani, Neil D. Burns, and C.J. Backhouse. 2019. "Transformational Leadership and Organizational Culture: The Situational Strength Perspective”. figshare. https://hdl.handle.net/2134/4585. 
This item was submitted to Loughborough's Institutional Repository (https://dspace.lboro.ac.uk/) by the author and is made available under the following Creative Commons Licence conditions.

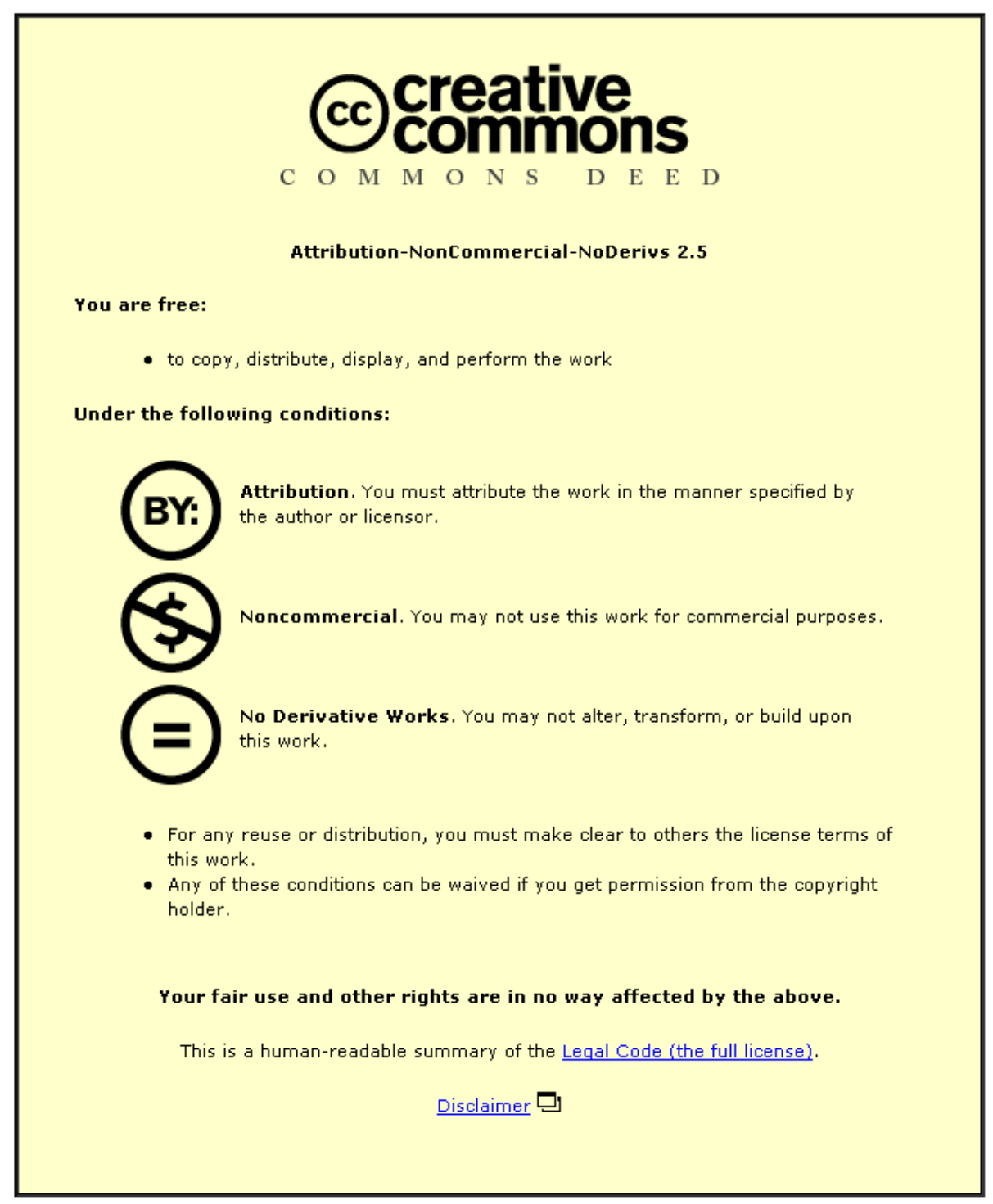

For the full text of this licence, please go to: http://creativecommons.org/licenses/by-nc-nd/2.5/ 


\title{
Transformational leadership and organizational culture: the situational strength perspective
}

\author{
S A Masood, S S Dani*, N D Burns, and C J Backhouse \\ Wolfson School of Mechanical and Manufacturing Engineering, Loughborough University, Loughborough, UK \\ The manuscript was received on 1 November 2005 and was accepted after revision for publication \\ on 6 February 2006.
}

DOI: $10.1243 / 09544054 J E M 499$

\begin{abstract}
This paper provides a new leadership alignment model incorporating various concepts focusing on leadership styles, organizational leadership, and situational strength. These concepts are brought together to introduce a leadership model, which looks not only at individual leadership and the effect of that on the organization but also at an organization as a system and how leadership behaviour and culture in individual departments or sections in an organization can be explained. Based on the work of Podsakoff et al., a 23-item measure of transformational leadership questionnaire was employed to evaluate transformational leaders. 339 followers from five manufacturing companies were asked to complete the questionnaire about their leaders and it was analysed to identify transformational leaders. The 76 manufacturing leaders then completed the organizational culture assessment instrument and a situational strength questionnaire, which was used to study the hypothesis.
\end{abstract}

Keywords: transformational leadership, organizational culture, leadership alignment model, situational strength

\section{INTRODUCTION}

Leadership is one of the most researched areas around the globe. It has gained importance in every walk of life from politics to business and from education to social organizations. Leaders must prepare to address the changes that will come about as a consequence of the globalization of the market. Business markets are becoming unstable, customer needs and desires are changing, and information flow is becoming more diverse and complex [1]. These changes require leaders and organizations that are able to respond to continuous changes in resources, technologies, marketing methods, and distribution systems.

This leadership project deals with the effect of enterprise context upon leadership behaviour and vice versa, in the manufacturing sector. There is little

*Corresponding author: Wolfson School of Mechanical and Manufacturing Engineering, Loughborough University, Loughborough, Leicestershire LE11 3TU, UK. email: S.Dani@ lboro.ac.uk theory or evidence concerning the kinds of leader behaviour required in various organizational settings. It is likely that either different behaviours or differential importance of behaviours will be associated with differences in organizations. Organizational variables such as size, organizational environment, type of strategy, technology, and organizational forms are likely to impose different demands on leaders and thus require specific leader behaviours [2]. The main focus of this research is to locate the process that runs in the background of all leadership activity, irrespective of whatever factors as described above affects the leadership activity. For this a psychological perspective to understanding the process is considered. Leadership research has always had the element of psychology associated with it in the different theories of traits, dispositions, motivations, etc., but these theories focus on the individual psyche of the leader. There has been sporadic research carried out using theories of organizational culture and situational strength and these focus on the psychological process of leadership. This is the focus of the research 
in this particular project. A study of the psychological focus will be made in order to support and provide towards understanding the effect of context upon the manufacturing leadership scenario.

\section{RESEARCH CONTEXT}

Burns [3] described leadership as 'a stream of evolving interrelationships in which leaders are continuously evoking motivational responses from followers and modifying their behaviour as they meet responsiveness or resistance, in a ceaseless process of flow and counter flow'. According to Bass [4], transformational leaders possess good visioning, rhetorical, and impression management skills, and they use these skills to develop strong emotional bonds with followers. The idealized influence aspect of transformational leadership is very close to the charismatic leadership; however, according to Bass [4] there are major differences between transformational and charismatic leaders. Charisma is a necessary but not sufficient component of transformational leadership. Some leaders may be charismatic but may have no transformational leadership characteristics. He used followers' perceptions or reactions to determine whether or not a leader was transformational.

Burns [3] described transformational leadership as a process in which 'leaders and followers raise one another to higher levels of morality and motivation'. Transformational leaders seek to raise the consciousness of followers by appealing to higher ideals and moral values such as liberty, justice, equality, peace, and humanitarian, and not to baser emotions such as fear, greed, jealousy, or hatred. In terms of Maslow's [5] need hierarchy, transformational leaders activate higher-order needs in followers. Research by Krishnan [6] suggests that superior performance is possible only through stimulating and motivating followers to higher levels of performance through transformational leadership. Superior performance is possible only by transforming followers' values, attitudes, and motives from a lower to a higher plane of arousal and maturity. Boehnke et al. [7] even found support for the claim that the main dimensions of leadership for extraordinary performance are universal. Studies have found significant and positive relationships between transformational leadership and the amount of effort that followers are willing to exert, satisfaction with the leader, ratings of job performance, and perceived effectiveness of leader [4]. In a research study conducted by Podsakoff et al. [8], an examination was made of the impact of transformational leadership behaviour on organizational citizenship behaviour and the role of followers' trust and satisfaction in that process. Six main transformational behaviours were identified as follows: articulating a vision, providing an appropriate model, fostering the acceptance of group goals, high performance expectations, individualized support, and intellectual stimulation. In contrast, organizational citizenship behaviours that were tested were the following: altruism, conscientiousness, sportsmanship, courtesy, and civic virtue. It is reported from this study that, although transformational leader behaviours had no direct effect on organizational citizenship behaviour, they influenced both employee trust and satisfaction. Employee trust influenced organizational citizenship behaviour, but employee satisfaction did not.

Transformational leadership could be potentially effective across a variety of situations, although certain contextual factors such as structure of the organization could facilitate the emergence and impact of transformational leadership [9]. Burns [3] also stated that transformational leadership may be exhibited by anyone in the organization in any type of position. It may involve people influencing peers and superiors as well as followers. It can occur in the day-to-day acts of ordinary people, but it is not ordinary or common. Bureaucratic organizations emphasize legitimate power and respect for rules and tradition, rather than influence based either on exchange or inspiration.

Transformational leadership has become a necessity in the post-industrial world of work [10]. It has been specified as an important mechanism for introducing organizational change and has received substantial research attention over the last two decades. As a result, there is now considerable knowledge about the transformational leadership phenomenon. It, however, has also generated several conceptual issues, such as the need for more knowledge about the relationship of transformational leadership with business contextual issues, as several researchers noted $[\mathbf{1 1}, \mathbf{1 2}]$ that transformational leadership research is at a stage where its conceptual examination is important. In the last two decades there has been accumulating evidence to suggest that transformational leadership is an influential form of leadership that is associated with high levels of individual and organizational performance (see, for example, references [13] and [14]). However, research on transformational leadership has not fully explored the question of what are the underlying processes and mechanisms by which transformational leaders exert their influence on followers and ultimately on performance [14]. As Yukl [15] concluded after reviewing research on this topic, 'a variety of different influence processes may be involved in transformational leadership, and different transformational behaviours may involve different 
influence processes'. In a study conducted by Scarborough [16] the emphasis to understand the underlying psychological processes was achieved by differentiating transformational leadership with transforming leadership. It is suggested in the study that transforming leadership as defined by Burns [3] requires a moral and ethical component to leadership behaviour, whereas transformational leadership as defined by Bass [4] contains more inspiration and charisma and does not require the moral component of transforming leadership. In the context of this paper, the main focus is to gain insight into the leadership of today's manufacturing companies within the perspective of the definition of transformational leadership. It is suggested that transformational leaders can have a dual effect, exerting their influence on followers through the creation of personal identification with the leader and social identification with the work unit, and that these different forms of identification can lead to differential outcomes.

Although Bass treated charisma and transformational leadership as distinct concepts, many researchers do not. The work of Tichy and DeVanna [17] on transformational leadership, for example, talks about articulating a vision, which enthuses followers and creates considerable loyalty and trust. This sounds very similar to charisma. Therefore, while conceptually they may be distinct, much of the writing fails to make it clear that they are. Trice and Beyer [18] made the distinction between charisma and transformational leadership by suggesting that charismatic leaders often create new organizations, while transformational leaders change existing organizations.

An important source of insight into the dynamics of transformational leadership is provided by research and theory on organizational culture [19]. Organizational culture is the 'glue' that holds the organization together as a source of identity and distinctive competence [20]. Can organizational cultures usefully be described in terms of how transactional or transformational they are [21]? The organizational culture is a learned pattern of behaviour, shared from one generation to the next [22]. It includes the values and assumptions shared by members about what is right, what is good, and what is important. Most organizational scholars and observers now recognize that organizational culture has a powerful effect on the performance and long-term effectiveness of organizations. Empirical research has produced an impressive array of findings, demonstrating the importance of culture to enhancing organizational performance [23-25]. Kotter and Heskett [26] defined culture as a critical factor in long-term financial success.

\section{ORGANIZATIONAL CULTURE}

Most organizational scholars and observers recognize that organizational culture has a powerful effect on the performance and long-term effectiveness of organizations. It was not until the beginning of the 1980s that organizational scholars began paying serious attention to the concept of culture (see, for example, references [22] and [27] to [29]). This is one of the few areas, in fact, in which organizational scholars led practising managers in identifying a crucial factor affecting organizational performance. Organizational culture has been an area in which conceptual work and scholarship have provided guidance for managers as they have searched for ways to improve the effectiveness of their organizations. Of course, there are many kinds or levels of culture that affect individual and organizational behaviour. At the broadest level, a global culture, such as a world religion's culture or the culture of the Eastern hemisphere would be the highest level. Researchers such as Hofstede [30], Aiken and Bacharach [31], and Trompenaars [32] have reported marked differences between continents and countries based on certain key dimensions. For example, national differences exist among countries on the basis of universalism versus particularism, individualism versus collectivism, neutrality versus emotionality, specificity versus diffuseness, focus on achievement versus ascription, focus on past versus present versus future, and an internal focus versus an external focus [32].

There are many kinds or levels of culture that affect individual and organizational behaviour. Researchers such as Hofstede [30] and Trompenaars [32] have reported marked differences between continents and countries based on certain key dimensions. An organization's culture is reflected by what is valued, the dominant leadership styles, the language and symbols, the procedures and routines, and the definitions of success that makes an organization unique [33]. Cameron and Quinn [33] have defined four different types of organizational culture. These are represented as adhocracy, clan, hierarchy, and market. They have suggested the different leadership styles or managerial styles pertaining to the respective organizational culture. When an organization is dominated by the hierarchy culture, the leadership style shown is that of organizing, controlling, monitoring, administering, coordinating, and maintaining efficiency. When an organization is dominated by the market culture, the managers are good at directing, producing results, negotiating, and motivating others. When the organization is dominated by the clan culture, the most effective leaders are parent figures, team builders, facilitators, nurturers, mentors, and 
supporters. Effective leaders in organizations dominated by the adhocracy culture tend to be entrepreneurial, visionary, innovative, creative, risk oriented, and focused on the future. Adhocracy leaders are rule breakers, for example, whereas hierarchy leaders are rule rein forcers. Clan leaders are warm and supportive, whereas market leaders are tough and demanding.

\subsection{The hierarchy culture}

The organizational culture compatible with this form is characterized by a formalized and structured place to work. Procedures govern what people do. Effective leaders are good coordinators and organizers. Maintaining a smooth-running organization is important. The long-term concerns of the organization are stability, predictability, and efficiency. Formal rules and policies hold the organization together. Large organizations and government agencies are generally dominated by a hierarchy culture, as evidenced by large numbers of standardized procedures, multiple hierarchical levels, and an emphasis on rule reinforcement.

\subsection{The market culture}

The term market is not synonymous with the marketing function or with customers in the marketplace. Rather, it refers to a type of organization, which functions as a market itself. It is oriented towards the external environment instead of internal affairs. It is assumed that a clear purpose and an aggressive strategy lead to productivity and profitability. A market culture, as assessed in the organizational culture assessment indicator (OCAI) questionnaire, is a results-oriented workplace. Leaders are hard-driving producers and competitors. They are tough and demanding. The glue that holds the organization together is an emphasis on winning. The long-term concern is on competitive actions and achieving stretch goals and targets. Success is defined in terms of market share and penetration. Outpacing the competition and market leadership are important.

\subsection{The clan culture}

The clan culture is called a clan because of its similarity to a family-type organization. They seemed more like extended families than economic entities. Instead of the rules and procedures of hierarchies or the competitive profit centres of markets, typical characteristics of clan-type firms were teamwork, employee involvement programmes, and corporate commitment to employees. These characteristics were evidenced by semi-autonomous work teams that received rewards on the basis of team (and not individual) accomplishment and that hired and fired their own members, quality circles that encouraged workers to voice suggestions regarding how to improve their own work and the performance of the company, and an empowering environment for employees. Some basic assumptions in a clan culture are that the environment can best be managed through teamwork and employee development, customers are best thought of as partners, the organization is in the business of developing a humane work environment, and the major task of management is to empower employees and to facilitate their participation, commitment, and loyalty.

The clan culture, as assessed in the OCAI questionnaire, is typified by a friendly place to work where people share much of themselves. It is like an extended family. Leaders are thought of as mentors and, perhaps, even as parent figures. The organization is held together by loyalty and tradition. Commitment is high. The organization emphasizes the long-term benefit of individual development with high cohesion and morale being important. Success is defined in terms of internal climate and concern for people. The organization places a premium on teamwork, participation, and consensus.

\subsection{The adhocracy culture}

The adhocracy culture, as assessed in the OCAI questionnaire, is characterized by a dynamic, entrepreneurial, and creative workplace. People stick their necks out and take risks. Effective leadership is visionary, innovative, and risk oriented. The glue that holds the organization together is commitment to experimentation and innovation. The emphasis is on being at the leading edge of new knowledge, products, and/or services. Readiness for change and meeting new challenges are important. The organization's long-term emphasis is on rapid growth and acquiring new resources. Success means producing unique and original products and services.

\section{SITUATIONAL STRENGTH}

The first researcher who formally recognized the importance of the leader, follower, and situation in the leadership process through his contingency model of leadership was Fiedler [34]. The situation may be the most ambiguous aspect of leadership, the nature of the task, the work setting, and the 
presence of formal rules and regulations are a few of the situational variables that can affect the leadership process. The situation can constrain or facilitate a leader's action and leaders can change different aspects of a situation in order to be more effective [35]. The concept of situational strength has been used to study the effect of various concepts of the leadership behaviour [36-38]. A framework of situational strength proposed by Mischel [39] segregated situations affecting human behaviour into two types: strong situation and weak situation. Strong situations are those in which most actors construe the situation in the same way, most draw similar conclusions as to appropriate responses, and most are motivated and able to respond. In strong situations, the situation itself provides incentives to make the appropriate response, and the necessary skills to respond are present in most individuals. A red traffic light is an example of a strong situation. Mischel [39] argued that in strong situations, but not weak situations, situational factors dominate individual differences in determining decision maker's courses of action. Thus, the behaviour of drivers at red lights is better predicted by the colour of the light than by the traits and dispositions of individual drivers, even though a few drivers do run red lights. Conversely, weak situations are defined by Mischel as those in which there is ambiguity about the meaning of the situation and the appropriateness of various responses, where incentives for any particular response are unclear, and where the ability of individuals to respond may vary. According to Mischel [39], individual differences play a more significant role in such situations (e.g. a yellow traffic light), since no clear directions are provided by the situation.

Among the most successful leadership models is a group characterized as contingency or situational models. The common theme of these models is that there is not one best way to lead; effective leaders adapt to their behaviours to each unique situation [40]. Situations may be defined entirely in terms of rule. Rules may specify what should and should not happen, what should be worn, and how to deal with different situations [41]. It is also likely that the type of employee in the strong-situation company will have adapted to that strong situation and will not challenge the system. This is not true of the weak situation where the individual is probably more used to, and accepting of, ambiguity and a lack of a strong company policy and is likely to deliver an individual response akin to their own ways of behaving in the particular situation. The trait approach is about how people behave in novel, ambiguous, or what is called 'weak' situations. Situations that are governed by clearly specified rules, demands, or organizational policies, i.e. 'strong' situations, often minimize the effects that traits have on behaviour [35].

\section{RESEARCH MODEL}

An important source of insight into the dynamics of transformational leadership is provided by research and theory on organizational culture [19]. Schein [42] provided the most comprehensive review and integration of this literature. Schein [42] defined culture as the basic assumptions and beliefs shared by members of a group or organization. Most organizational scholars and observers now recognize that organizational culture has a powerful effect on the performance and long-term effectiveness of organizations [33]. Bass [43] presumed that the clan culture provides more potential for transformational leadership, and the market culture for transactional leadership. As indicated by Kark and Shamir [14] research on transformational leadership has not fully explored the mechanisms by which transformational leaders exert their influence on followers and ultimately on performance. It is thus necessary to gather data from manufacturing leaders to gain further insights into transformational leadership in manufacturing organizations. Figure 1 presents a framework that represents organizational culture, leadership style, and situational strength in a cohesive structure. It consists of a four-quadrant grid organized around two factors, namely leadership style and organizational culture, with the quadrants as follows:

quadrant I: transformational leadership and adhocracy-clan culture;

quadrant II: non-transformational leadership and adhocracy-clan culture;

quadrant III: transformational leadership and hierarchy-market culture;

quadrant IV: non-transformational leadership and hierarchy-market culture.

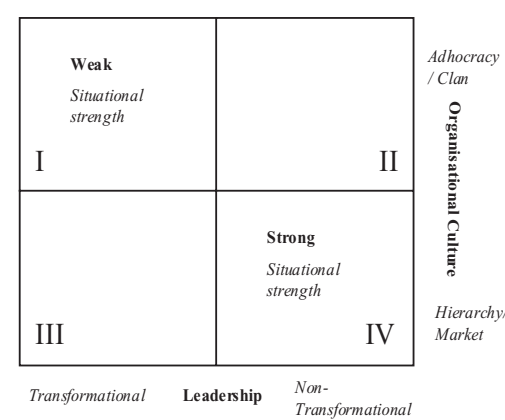

Fig. 1 Framework depicting the effect of situational strength on transformational leadership and organizational culture 
Considering the concept of situational strength within the perspective of the framework it can be assumed that a combination of transformational leadership with adhocracy-clan culture (quadrant I) would generate a weak situational strength in the organization providing more discretion and capability to the followers to manage their tasks. The combination of non-transformational and hierarchy-market (quadrant IV) would generate a strong situational strength in the organization, providing strict guidelines and structure to the followers for completing their tasks.

From this model the following can be hypothesized.

1. Transformational leaders prefer to work in an adhocratic or clan-type culture.

2. Non-transformational leaders prefer to work in hierarchy-market-type cultures.

3. Transformational leaders prefer to create working environments with a weak situational strength for their followers.

4. Non-transformational leaders prefer to create working environments with a strong situational strength for their followers.

The framework depicts the organizational perspective in regard to the leadership style, culture, and the situational strength. It can be argued that there may be a certain organizational culture but different departments in the organization may have their respective cultures. Also, each individual department may be headed by a leader who may influence the culture and situational strength of the department. This is shown in Fig. 2, which depicts the internal leadership and cultural systems in organizations.

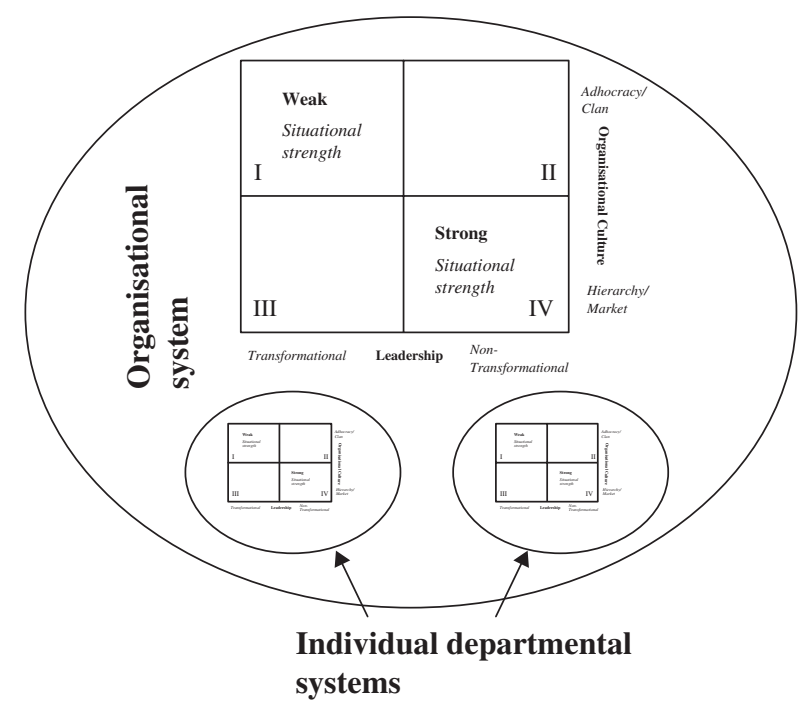

Fig. 2 Leadership and cultural systems within organizations

\section{RESEARCH METHODOLOGY}

The sample selected for this research was a total of 339 followers consisting of leader-subordinate dyads at middle and lower levels of management for 76 leaders from five manufacturing companies in Pakistan. The organizations used in the testing included three large heavy-weight vehicle manufacturing organizations, one medium-weight vehicle manufacturing organization, and one discrete parts manufacturing industry. Three organizations of the sample were located in the western parts of Pakistan and two organizations were located in the eastern parts of Pakistan. Three of the organizations are government owned, whereas the other two are privately owned. The large heavy-weight vehicles manufacturing organization has in the range of 300-500 employees with 15-25 leaders, the medium-weight vehicles manufacturing organization has 100-150 employees with 10-15 leaders, and the discrete parts manufacturing industry has 30-60 employees with 5-8 leaders. To manage the study within the time frame of the research work, it was decided to select a sample size of five manufacturing organizations including small to large manufacturing scale organizations based on a convenience sampling strategy [44].

In all the five organizations, employees concerned with manufacturing, from the shop floor to the top management were asked to complete a questionnaire based on the work of Podsakoff et al. [8]. (For more information on the questionnaire contact S.Dani@lboro.ac.uk.) Transformational leadership characteristics were measured using the 23-item questionnaire based on the measures of transformational leadership utilized by Podsakoff et al. [8] for their research on transformational leadership. The measure includes six transformational leadership behaviours: articulating a vision, providing an appropriate model, fostering the acceptance of group goals, high performance expectations, individualized support, and intellectual stimulation. A seven-point scale ranging from 1 (strongly disagree) to 7 (strongly agree) was used. All the 339 respondents completed the questionnaire. The responses were then clustered for each of the 76 leaders and the mean calculated. The Podsakoff et al. [8] transformational leadership questionnaire was useful in segregating the sample of 76 leaders into transformational and non-transformational leaders. The variables used in the questionnaire were primarily transformational variables; hence even a low score meant that the leader had some qualities of a transformational leader. However, in the context of this research, as it was decided to focus on high transformational behaviour, all leaders having a score of not less than 4.0 (mean, 4.0) were considered as transformational leaders and the rest 
of the sample was considered to be non-transformational. Out of the sample of 76 leaders, thus 37 leaders were considered to be transformational. The leaders who had a score between 3.0 and 4.0 could be considered to be transformational on the basis of certain criteria, but in this research it was decided to consider only those leaders as transformational who had a score over 4.0.

The 76 leaders were then asked to complete two questionnaires. (For more information on the questionnaire contact S.Dani@lboro.ac.uk.) One dealt with the issues of situational strength, focusing on the aspects of discretion that leaders provided to their followers, whereas the other was the OCAI questionnaire developed by Cameron and Quinn. The OCAI questionnaire was used to obtain an insight into the organizational culture based on the OCAI typology, namely adhocracy, clan, hierarchi$\mathrm{cal}$, and market. The respondents were asked to complete the OCAI questionnaire to depict their perception of the culture in their organizations. The questionnaire measuring situation strength consisted of six questions, which looked at the level of discretion provided by the leaders to their followers to take decisions, monitoring of followers, having a clear standard of praise and punishment, setting of clear goals, and level of discipline in the working environment. A five-point scale ranging from 1 (does not emphasize) to 5 (strongly emphasizes) was used. Leaders having a score of more than 18.0 (mean score, 18.0) were termed to perceive the situations that they work in as having a strong situational strength. Leaders having a score of less than 18.0 were termed to perceive the situations that they work in as having a weak situational strength. For leaders with scores of 18 and 19, the score for the question on discretion ruled whether they were in the strong or weak category. Where the question on discretion generated a high score on emphasizing discretion given to followers, the situation was termed as weak and, where there was no discretion given to followers, the situation was termed as strong.

\section{DISCUSSION AND CONCLUSION}

After analysing the questionnaires, the data were inserted into the research model (Fig. 3). It can be clearly seen that the preference of transformational leaders is to create a working environment with a weak situational strength for their followers. It can also be inferred that non-transformational leaders would generally prefer to create working environments with a strong situational strength for their followers. It can also be seen that the results did not provide a complete correlation between type of

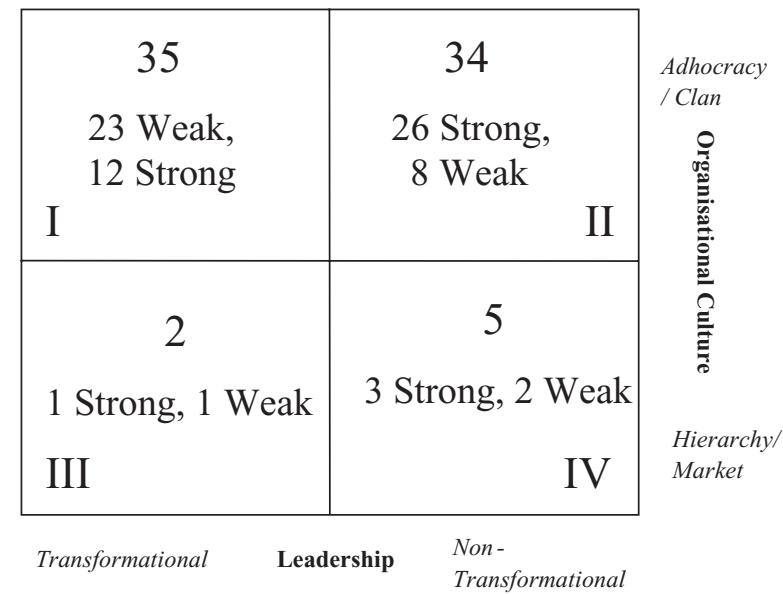

Fig. 3 The research model incorporating the results

leadership and situational strength: 65 per cent of the transformational leaders showed a preference for a weak situational strength, whereas 35 per cent showed a preference for strong situational strength. Studying each variable affecting the situational strength and the leader's preference could rectify the discrepancy in these results. Similarly, 74 per cent of the non-transformational leaders showed a preference for a strong situational strength, whereas 26 per cent showed a preference for a weak situational strength.

The results from the OCAI questionnaire showed some discrepancy between the hypothesized research model and the actual data. The hypothesis that transformational leaders prefer to work in adhocratic or clan-type culture has been supported by the data: 94.5 per cent of the transformational leaders showed a preference for a clan culture, whereas only 5.5 per cent showed a preference for a hierarchymarket culture. The discrepancy arises in the preference of non-transformational leaders. The hypothesis that non-transformational leaders prefer to work in hierarchy-market-type cultures is not supported. A detailed analysis regarding the cultural preference of non-transformational leaders is required to ascertain whether the leaders in this sample have not been able to draw out the differences between clan and hierarchy as the hierarchy culture is next after clan in the evolution of organizational culture. This hypothesis could be supported if based on the previous hypothesis regarding situational strength. Since nontransformational leaders showed a preference for strong situational strength and since the hierarchymarket cultures are associated with strong situational strength, it can be inferred that nontransformational leaders would show a preference for working in hierarchy-market-type cultures.

In the context of this research, the systems model of leadership and culture proposed in Fig. 2 
is also important as the respondents who were termed as leaders were not only the top management but also were project directors, general managers, deputy general managers, officers in charge of manufacturing units, managers, and foremen. The respondents were termed as leaders in the context of this research by virtue of being in charge of a working group and had people reporting to them. Hence, the systems model is important as it depicts that, even though a leader (top management) has a certain preference for organizational culture and situational strength, a leader (as defined in the context of this research) of a section in the organization may have his or her own preference for culture and situational strength. This may lead to the leader in the section either changing their preference in order to align with the organizational preference (top management) or maintaining the difference but finding a way to align with the organizational goals. The top management, however, if not satisfied with the difference in the preferences between the section and the organization, either may replace the leader with one who maintains their preference or would initiate to transform the leadership style of the section leader.

The research model is particularly useful for deciding whether it would be possible to transform leadership style without changing cultural and situational strength preferences. As shown in Fig. 4, it can be hypothesized that, if the leader is in quadrant III and would like to maintain his or her transformational style of leadership, he or she should change the preference for culture to adhocracy-clan. If the leader is in quadrant II and would like to maintain his or her non-transformational leadership style, he or she should change the preference for culture to hierarchy-market.

The study has been successful in examining transformational leadership with the concepts of

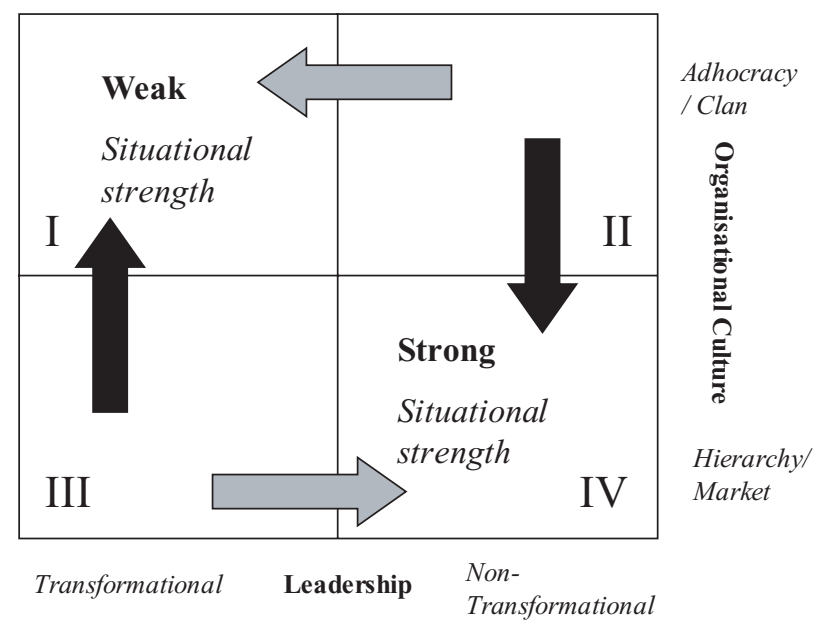

Fig. 4 The alignment model of leadership situational strength and organizational culture. The importance of the study stems from the assumption that transformational leadership behaviour can influence to a great degree how followers work and are given freedom to work in organizations. This is useful when the human resource departments of manufacturing companies study issues of motivation, job satisfaction, employee morale, and employee training. Knowing that the leadership is transformational can make it easier for change and innovation in organizations as it can be inferred that transformational leaders will thus try to create weak situations where employees are given discretion and freedom to take decisions in their work, hence increasing employee morale and confidence. Also, the clan culture associated with weak situations promotes team working and innovation. One of the major limitations for generalizing these results is that all the companies selected for the study were based in Pakistan, and this may bring out some differences in the results if they are studied as an effect of national cultures. The proposed alignment model needs further testing and would benefit by testing it within different national cultures. This would provide more support and would help to generalize it.

\section{ACKNOWLEDGEMENTS}

The authors would like to thank the Engineering and Physical Sciences and Research Council, UK, and The Ministry of Education, Government of Pakistan, for the support they have rendered for this project.

\section{REFERENCES}

1 Bass, B. M. and Avolio, B. J. Developing transformational leadership: 1992 and beyond. J. Eur. Ind. Training, 1992, 14(5), 21-27.

2 House, R. J. and Aditya, R. N. The social scientific study of leadership: quo vadis? J. Mgmt, 1997, 23(3), 409-473.

3 Burns, J. M. Leadership, 1978 (Harper \& Row, New York).

4 Bass, B. M. Leadership and performance beyond expectations, 1985 (Free Press, New York).

5 Maslow, A. Toward a psychology of being, 1968 (Van Nostrand Reinhold, New York).

6 Krishnan, V. R. Value systems of transformational leaders. Leadership Orgn Dev. J., 2001, 22(3), 126-131.

7 Boehnke, K., Bontis, N., and DiStefano, J. J. A. C. Transformational leadership: an examination of crossnational differences and similarities. Leadership Orgn Dev. J., 2003, 24(1), 5-15.

8 Podsakoff, P. M., MacKenzie, S. B., and Fetter, R. Transformational leaders behaviours and their effects on followers' trust in leader, satisfaction, and organizational citizenship behaviours. Leadership Q., 1990, 1(2), 107-142. 
9 Shamir, B. and Howell, J. M. Organizational and contextual influences on the emergence and effectiveness of charismatic leadership. Leadership Q., 1999, 10(2), 257-283.

10 Bass, B. M. The ethics of transformational leadership. In Kellogg leadership studies project: transformational leadership, working papers, 1997 (Academy of Leadership Press, USA). http://www.academy.umd.edu/ publications/klspdocs/bbass_p1.htm

11 Bass, B. M. Two decades of research and development in transformational leadership. Eur. J. Work Organizational Psychol., 1999, 8, 9-32.

12 Conger, J. A. Charismatic and transformational leadership in organizations: an insider's perspective on these developing streams of research. Leadership Q., 1999, 10(2), 145-169.

13 Barling, J., Weber, T., and Kelloway, E. K. Effects of transformational leadership training on attitudinal and financial outcomes: a field experiment. J. Appl. Psychol., 1996, 81, 827-832.

14 Kark, R. and Shamir, B. The dual effect of transformational leadership: priming relational and collective selves and further effects on followers. Transformational Charismatic Leadership, 2002, 2, 67-91.

15 Yukl, G. Leadership in organisations (4th edition), 1997 (Prentice-Hall, Englewood Cliffs, New Jersey).

16 Scarborough, J. D. Transforming leadership in the manufacturing industry. J. Ind. Technol., 2001, 17(2), $1-13$.

17 Tichy, N. and DeVanna, M. The transformational leader, 1986 (John Wiley, New York).

18 Trice, H. M. and Beyer, J. M. Cultural leadership in organizations. Orgn Sci., 2,149-169.

19 Yukl, G. A. Leadership in organizations, 2nd edition, 1989 (Prentice-Hall, Englewood Cliffs, New Jersey).

20 Bolman, L. G. and Deal, T. E. Reframing organisations: artistry, choice and leadership, 1991 (Jossey-Bass, San Francisco, California).

21 Bass, B. M. Transformational leadership: industrial, military, and educational impact, 1998 (Lawrence Erlbaum Associates Inc., Mahwah, New Jersey).

22 Deal, T. E. and Kennedy, A. A. Corporate cultures: the rights and rituals of corporate life, 1982 (Addison- Wesley, Reading, Massachusetts).

23 Cameron, K. S. and Ettington, D. R. The conceptual foundations of organisational culture. Higher education: handbook of theory and research, 1988, pp. 356-396 (Agathon, New York).

24 Denison, D. Corporate culture and organisational effectiveness, 1990 (John Wiley, New York).

25 Trice, H. and Beyer, J. The cultures of work organisations, 1993 (Prentice-Hall, Englewood Cliffs, New Jersey).

26 Kotter, J. P. and Heskett, J. L. Corporate culture and performance, 1992 (Free Press, New York).

27 Ouchi, W. G. Theory Z: how American business can Meet the Japanese challenge, 1981 (Addison-Wesley, Reading, Massachusetts).
28 Pascale, R. and Athos, A. The art of Japanese management, 1981 (Simon \& Schuster, New York).

29 Peters, T. J. and Waterman, Jr, R. H. In search of excellence: lessons from America's best run companies, 1982 (Harper \& Row, New York).

30 Hofstede, G. Culture's consequences, 1980 (Sage Publications, London).

31 Aiken, M. and Bacharach, S. B. Culture and organization structure and process: a comparative study of local government administration bureaucracies in the Wallon and Flemish regions of Belgium. In Organisations alike and unlike (Eds C. J. Lammers and D. J. Hickson), 1979, 215-250 (Routledge, London).

32 Trompenaars, F. Riding the waves of cultures: understanding cultural diversity in business, 1992 (Nicholas Brealey Publishing, London).

33 Cameron, K. S. and Quinn, R. E. Diagnosing and changing organisational culture, 1999 (Addison-Wesley Longman, Reading, Massachusetts).

34 Fiedler, F. E. A theory of leadership effectiveness, 1967 (McGraw-Hill, New York).

35 Hughes, R. L., Ginnrtt, R. C., and Curphy, G. J. Leadership: enhancing the lessons of experience, 1993 (Richard, D. Irwin, Inc., Homewood Illinois).

36 Carpenter, M. A. and Golden, B. R. Perceived managerial discretion: a study of cause and effect. Strategic Mgmt J., 1997, 18(3), 187-206.

37 Mullins, J. W. and Cummings, L. L. Situational strength: a framework for understanding the role of individuals in initiating proactive strategic change. J. Organizational Change Mgmt, 1999, 12(6), 462-479.

38 Carpenter, M. A. and Fredrickson, J. W. Top management teams, global strategic posture, and the moderating role of uncertainty. Acad. Mgmt J., 2001, 44(3), 533-545.

39 Mischel, W. The interaction of person and situation. In Personality at the crossroads: current issues in interactional psychology (Eds D. Magnusson and N. Endler), 1977, Ch. 25 (Lawrence Erlbaum Associates, Mahwah, New Jersey).

40 Hiebert, M. and Klatt, B. The encyclopaedia of leadership. A practical guide to popular leadership theories and techniques, 2001 (McGraw-Hill, New York).

41 Magnusson, D. and Endler, N. S. Personality at the crossroads: current issues in interactional psychology, 1977 (Lawrence Erlbaum Associates, Mahwah, New Jersey).

42 Schein, E. H. Organizational culture and leadership, 1985 (Jossey-Bass, San Francisco, California).

43 Bass, B. M. Bass and Stogdill's handbook of leadership: theory, research, and management applications, 3rd edition, 1990 (Free Press, New York).

44 Bryman, A. and Cramer, D. Quantitative data analysis with SPSS 12 and 13: a guide for social scientists, 2005 (Routledge, Hove, East Sussex). 